\title{
EFFECT OF MINERAL NPK AND ORGANIC FERTILIZATION ON GROWTH, YIELD, ESSENTIAL OIL AND CHEMICAL COMPOSITION OF CORIANDER PLANTS
}

\author{
F.S. Badran, A.A. El-Sayed, E.A. Hassan and A.F. Rekaby \\ Hort. Dept., Fac. Agric., Minia Univ., Egypt.
}

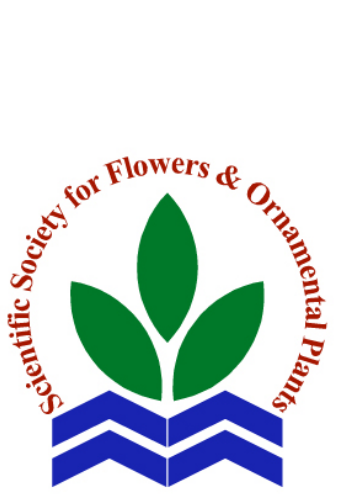

Scientific J. Flowers \& Ornamental Plants, 5(2):161-170 (2018).

Received:

11/3/2018

Accepted:

$19 / 3 / 2018$

ABSTRACT: A field trial was conducted at Esna, Luxor Governorate, Egypt during 2012/2013 and 2013/2014 seasons to study the effect of mineral NPK and organic fertilization on growth, yield, essential oil and herb N, P and K \% of Coriandrum sativum, L. plants.

The obtained results revealed that all studied characters of growth, yield, essential oil and herb \% of NPK were significantly augmented due to the use of both low and high NPK fertilization rates with the high one giving the highest values.

Concerning organic fertilization, the different growth traits (plant height, stem diameter and herb dry weight), yield and yield component characters (number of umbels/plant and fruit yield per plant and per fed), essential oil parameters (percent and yield per plant and per fed) and NPK \% in the herb were gradually increased parallel to the gradual increase in compost level.

The combined treatment between the low NPK rate (50 g kristalon/10.8 $\mathrm{m}^{2}$ plot)and medium compost level (10 ton/fed) resulted in better fruit and essential oil yield than that obtained from the high NPK rate. So, the possibility of substituting one half of the mineral NPK dose by the medium compost level is justified.

Key words: Coriandrum sativum, mineral NPK, organic fertilization, growth, essential oil.

\section{INTRODUCTION}

Coriander (Coriandrum sativum, L.) plants are belonging to Family Apiaceae (Umbelliferae) and widely grown in Upper Egypt regions like Minia and Assiut Governorates as a winter annual herb. The fruits contain $0.2-0.4 \%$ essential oil which contains $65-70 \%$ linalool and pinene. It is used as a flavor for meats, canned foods, spicy, sauces, baked goods, confectionery and perfumes. In addition, coriander stimulates the flow of digestive secretion which is useful as a carminative and laxative and in the treatment of intestinal disorders and has antispasmodic and expectorant properties, (Bedoukian, 1967 and Stary and Jirasck, 1975).

The importance of chemical fertilizers in increasing growth, yield, essential oil and chemical composition of different aromatic seed plants was revealed on many plants such as fennel (Badran et al., 2001; Badran et al., 2007 and Tanious, 2008); cumin (Safwat and Badran, 2002); anise (Badran et al., 2003 a and b; Bhuvaneshwari et al., 2003 and Hemdan, 2008); Ammi visnaga (Joshi et al., 2003 and Kenawy, 2010); black cumin (Badran et al., 2009; Gahory, 2012 and Badran et al., 2012) and coriander (Badran et al., 2011 and 2013). Nowadays, there is a strong trend towards minimizing or reducing the use of mineral fertilizers and substitute 


\section{F.S. Badran et al.}

them by organic fertilizers which are less expensive and environmentally safe in cultivating aromatic and medicinal plants. In this regard, a good number of investigators pointed out the role of organic fertilizers in augmenting various aromatic seed plants. Examples are fennel (Badran et al., 2001; Fernandez et al., 2002; Badran and Safwat, 2004; Tanious, 2008 and Moradi et al., 2011); cumin (Safwat and Badran, 2002 and Badran et al., 2007); Ammi visnaga (Younis et al., 2004 and Kenawy, 2010); black cumin (Shoor et al, 2010 and Gahory, 2012); anise (Hemdan, 2008) an coriander (Abdalla, 2009).

The aim of this work is to investigate the effect of reducing chemical fertilization through using compost.

\section{MATERIALS AND METHODS}

The present study was conducted at Esna, Luxor Governorate, Egypt during $2012 / 2013$ and 2013/2014 seasons to investigate the response of vegetative growth, yield, essential oil and chemical composition of coriander plants to chemical and organic fertilization treatments.

Seeds of coriander plants were sown on the second week of Nov. 2012 and 2013 in
$3 \times 3.6$ meter plots with $60 \mathrm{~cm}$ distance between the rows and $30 \mathrm{~cm}$ between hills within each row. So, each plot contained 6 rows and 60 hills. The plants were thinned twice before the application of mineral fertilization (2 plants were left per each hill). Physical and chemical analysis of the experimental soil is shown in Table (a).

A split- plot design with three replicates was used in this experiment. The main plot included 4 compost levels, (0, 5, 10 and 15 ton/fed), while the sub-plot included 3 mineral NPK rates $\left(0,50\right.$ and $100 \mathrm{~g} / 10.8 \mathrm{~m}^{2}$ plot of kristalon 20:20:20). Compost amounts were added during soil preparation, while kristalon amounts were applied there times, after one month from planting date and at three weeks interval thereafter. Physical and chemical properties of the used compost are shown in Table (b).

Data were recorded for plant height (cm), stem diameter, herb dry weight (g/plant), number of umbels/plant and fruit yield per plant (g) and per fed (kg). Essential oil \% was determined according to Gad et al. (1963) and essential oil yield per plant (ml) and per fed (liter) were calculated. Herb N, P and $\mathrm{K} \%$ were determined according to Page et al. (1982).

Table a. Physical and chemical analysis of the soil.

\begin{tabular}{lccc}
\hline \multicolumn{1}{c}{ Character } & Value & Character & Value \\
\hline Soil type & Sandy loam & Total N (\%) & 0.06 \\
Sand (\%) & 58.50 & Avail. P (\%) & 6.10 \\
Silt (\%) & 17.70 & Exch. K (mg/100 g) & 1.18 \\
Clay (\%) & 23.80 & Fe & 5.04 \\
Org. matt. (\%) & 0.63 & DPTA Cu & 1.32 \\
CaCO $\mathbf{3}$ (\%) & 6.15 & Ext. (ppm) Zn & 1.94 \\
pH 1: 2.5 & 7.84 & & Mn \\
E.C. mmhos/cm & 1.06 & & 10.60 \\
\hline
\end{tabular}

Table b. Physical and chemical properties of the used compost.

\begin{tabular}{lclc}
\hline Character & Value & Character & Value \\
\hline Weight of 1m $\mathbf{m}^{3}$ dry & $450-500 \mathrm{~kg}$ & Tota N (\%) & $1.4-1.8$ \\
Moisture (\%) & $20-26$ & Total P (\%) & $0.4-0.6$ \\
O.M. (\%) & $40-48$ & Total K (\%) & $0.8-1.2$ \\
pH ( 1: 2.5) & $7.5-8.5$ & Fe (ppm) & $1500-2000$ \\
EC mmhos/cm & $4-6$ & Mn (ppm) & $100-150$ \\
C/N ratio & $16-19$ & Zn (ppm) & $40-80$ \\
& & Cu (ppm) & $160-240$ \\
\hline
\end{tabular}


All obtained data were statistically analyzed following the L.S.D. method described by Little and Hills (1978).

\section{RESULTS AND DISCUSSION}

\section{Vegetative growth characters:}

All of the three vegetative growth traits, plant height, stem diameter and herb dry weight/plant of coriander plants were significantly increased, in both seasons, due to the use of compost at all levels over those of control plants, as shown in Table (1). Among the three used levels, the increase in the three growth traits was parallel to the gradual increase in compost level with the highest values being obtained due to the high compost level (15 ton/fed) as clearly shown in Table (1). The role of organic fertilization in augmenting vegetative growth was revealed by Badran and Safwat (2004) on fennel, Younis et al. (2004) and Kenawy (2010) on Ammi visnaga, Badran et al. (2007) on cumin, Hemdan (2008) on anise Abdalla (2009) on coriander and Gahory (2012) on black cumin.

Concerning NPK fertilization treatments, significant differences were obtained, for the three vegetative growth characters in both seasons, due to both the low and high NPK fertilization treatments in comparison with those of control plants. Moreover, the high NPK level (100 g/10.8 $\mathrm{m}^{2}$ plot) gave significantly taller plants, thicker stems and heavier herb dry weight than the low NPK level (50 g/10.8 $\mathrm{m}^{2}$ plot) as shown in Table (1). Many authors emphasized the role of NPK mineral fertilization in enhancing vegetative growth such as Badran et al. (2001) and Badran et al. (2007) on fennel, Safwat and Badran (2002) on cumin, Bhuvaneshwari et al. (2003) and Badran et al. (2003b) on anise, Badran et al. (2009) on black cumin and Badran et al. (2011) on coriander.

The interaction between organic and mineral fertilization treatments was significant for plant height, stem diameter and herb dry weight per plant in both seasons, (Table, 1). The highest values for the three traits were obtained when coriander plants were supplied with either 10 or 15 ton compost/fed in combination with $100 \mathrm{~g} / 10.8$ $\mathrm{m}^{2}$ plot of NPK.

\section{Yield and yield components:}

Table (2) indicated that number of primary umbels/plant and fruit yield per plant and per fed were significantly increased, in both seasons, due to the application of compost at all tested rates (5, 10 or 15 ton/fed) over those of unfertilized plants. The increase in these traits was gradual and parallel to the gradual increase in compost level, however, no significant differences were detected between 10 and 15 ton/fed levels in both season. Fruit yield/fed was increased by 25.9 and $30.4 \%$ in the first season and by 24.5 and $29.5 \%$ in the second one due to the use of 10 and 15 ton compost/fed in comparison with control plants. In agreement with these results were those obtained on fennel (Badran et al., 2001; Badran and Safwat, 2004 and Tanious, 2008); cumin (Safwat and Badran, 2002 and Badran et al., 2007) and black cumin (Shoor et al., 2010 and Gahory, 2012).

Both the low and high NPK fertilization levels caused significant increases in number of umbels and fruit yield per plant and fed, in both seasons, over those of control plants as shown in Table (2). Moreover, significant differences were detected, for the three traits in both seasons, between the low and the high NPK fertilization levels in favour of the high one (100 g/10.8 $\mathrm{m}^{2}$ plot). Numerically fruit yield/fed was increased by 21.7 and $32.1 \%$ in the first season and by 20.1 and $29.9 \%$ in the second one due to the low and high NPK levels, respectively over the yield of the control plants. The efficiency of mineral NPK in augmenting fruit yield of different aromatic plants was revealed by Safwat and Badran (2002) on cumin; Joshi et al. (2003) on Ammi visnaga; Buhvaneshwari et al. (2003) and Badran et al. (2003a) on anise, Badran et al. (2009) and Badran et al. (2012) on black cumin and Badran et al. (2013) on coriander. 
Table 1. Effect of mineral and organic fertilization treatments on some vegetative growth characters of coriander plants during 2012/2013 and 2013/2014 seasons.

\begin{tabular}{|c|c|c|c|c|c|c|c|c|c|c|}
\hline \multirow{3}{*}{$\begin{array}{l}\text { Compost level } \\
\text { (ton/fed) (A) }\end{array}$} & \multicolumn{10}{|c|}{ NPK fertilization treatments (g/10.8 $\mathrm{m}^{2}$ plot) (B) } \\
\hline & $\mathbf{0}$ & 50 & 100 & & M. (A) & $\mathbf{0}$ & 50 & 100 & & M. (A) \\
\hline & \multicolumn{5}{|c|}{ First season } & \multicolumn{5}{|c|}{ Second season } \\
\hline & \multicolumn{10}{|c|}{ Plant height (cm) } \\
\hline $\mathbf{0}$ & 81.0 & 100.4 & 115.2 & & 98.9 & 82.2 & 103.5 & 116.9 & & 100.9 \\
\hline 5 & 92.1 & 112.8 & 127.5 & & 110.8 & 95.7 & 114.3 & 130.4 & & 113.5 \\
\hline 10 & 101.6 & 119.1 & 131.5 & & 117.4 & 100.0 & 122.3 & 136.8 & & 119.7 \\
\hline 15 & 105.2 & 124.3 & 137.1 & & 122.2 & 104.4 & 126.7 & 140.6 & & 123.9 \\
\hline Mean NPK & 95.0 & 114.2 & 127.8 & & & 95.6 & 116.7 & 131.2 & & \\
\hline \multirow[t]{2}{*}{ L.S.D. 5\% } & A: $\quad 8.4$ & B: & 5.8 & AB: & 11.6 & A: 7.9 & B: & 6.0 & AB: & 12.0 \\
\hline & \multicolumn{10}{|c|}{ Stem diameter $(\mathrm{mm})$} \\
\hline $\mathbf{0}$ & 8.0 & 11.7 & 13.2 & & 11.0 & 7.9 & 11.6 & 13.3 & & 10.9 \\
\hline 5 & 9.5 & 13.6 & 15.1 & & 12.7 & 9.6 & 13.8 & 15.0 & & 12.8 \\
\hline 10 & 11.1 & 15.0 & 16.9 & & 14.3 & 11.2 & 15.3 & 16.8 & & 14.4 \\
\hline 15 & 12.0 & 15.8 & 17.5 & & 15.1 & 12.2 & 16.0 & 17.4 & & 15.2 \\
\hline Mean NPK & 10.2 & 14.0 & 15.5 & & & 10.2 & 14.2 & 15.4 & & \\
\hline \multirow[t]{2}{*}{ L.S.D. 5\% } & A: 1.2 & B: & 1.2 & AB: & 2.4 & A: 0.8 & B: & 1.1 & $\mathrm{AB}:$ & 2.2 \\
\hline & \multicolumn{10}{|c|}{ Herb dry weight (g/plant) } \\
\hline $\mathbf{0}$ & 30.4 & 42.1 & 48.7 & & 40.4 & 31.2 & 44.0 & 49.7 & & 41.6 \\
\hline 5 & 36.4 & 53.2 & 60.2 & & 49.3 & 36.8 & 54.6 & 61.2 & & 50.9 \\
\hline 10 & 39.9 & 58.3 & 66.8 & & 55.0 & 40.3 & 60.2 & 68.0 & & 56.2 \\
\hline 15 & 43.5 & 65.6 & 73.1 & & 60.7 & 43.7 & 68.1 & 73.2 & & 61.7 \\
\hline Mean NPK & 37.8 & 54.8 & 62.2 & & & 38.0 & 56.7 & 63.0 & & \\
\hline L.S.D. 5\% & A: 3.5 & B: & 4.1 & $\mathrm{AB}:$ & 8.2 & A: 4.0 & B: & 4.6 & $\mathrm{AB}:$ & 9.2 \\
\hline
\end{tabular}

Concerning the interaction between organic and mineral NPK fertilization treatments, it was significant, in both seasons for the three studied traits, with the highest values being obtained due to supplying coriander plants with $100 \mathrm{~g}$ NPK/10.8 $\mathrm{m}^{2}$ plot in combination with either 10 or 15 ton/fed compost (Table, 2).

\section{Essential oil parameters:}

Data presented in Table (3) showed that the gradual increase in compost level was accompanied by a gradual and consistent increase in each of essential oil percent and yield per plant and per fed with significant differences between control plants, on one side, and the three compost fertilized plants in both seasons. Essential oil yield/fed was increased by 70.4 and $63.5 \%$ in the first and second seasons due to the use of compost at 15 ton/fed in comparison with control plants. The promotive influence of organic fertilization was obtained on fennel (Badran et al., 2001; Badran and Safwat, 2004 and Moradi et al., 2011); cumin (Safwat and Badran, 2002 and Badran et al., 2007); anise (Hemdan, 2008) and coriander (Abdalla, 2009).

Regarding NPK mineral fertilization, significant differences were detected between each two successive treatments, zero, low and high levels, in both seasons for each of essential oil \% and yield per plant and per feddan as clearly shown in Table (3). The increase in essential oil yield/fed reached 38.6 and $66.2 \%$ in the first season and35.8 and $56.8 \%$ in the second one due to the low (50 g NPK/plot) and high (100 g 
Table 2. Effect of mineral and organic fertilization treatments on yield components of coriander plants during 2012/2013 and 2013/2014 seasons.

\begin{tabular}{|c|c|c|c|c|c|c|c|c|c|c|}
\hline \multirow{3}{*}{$\begin{array}{l}\text { Compost level } \\
\text { (ton/fed) (A) }\end{array}$} & \multicolumn{10}{|c|}{ NPK fertilization treatments (g/10.8 $\mathrm{m}^{2}$ plot) (B) } \\
\hline & c & & 50 & 100 & M. (A) & $\mathbf{0}$ & 50 & 100 & & M. (A) \\
\hline & \multicolumn{6}{|c|}{ First season } & \multicolumn{4}{|c|}{ Second season } \\
\hline & \multicolumn{10}{|c|}{ Number of umbels/plant } \\
\hline $\mathbf{0}$ & \multicolumn{2}{|c|}{21.8} & 25.4 & 27.6 & 24.9 & 21.4 & 25.6 & 28.0 & & 25.0 \\
\hline 5 & \multicolumn{2}{|c|}{25.0} & 29.8 & 32.6 & 29.1 & 24.9 & 30.1 & 33.4 & & 29.5 \\
\hline 10 & \multicolumn{2}{|c|}{27.3} & 34.2 & 37.9 & 33.1 & 27.6 & 34.2 & 37.7 & & 33.2 \\
\hline 15 & \multicolumn{2}{|c|}{28.0} & 36.8 & 40.2 & 35.0 & 28.2 & 37.0 & 40.4 & & 35.2 \\
\hline Mean NPK & \multicolumn{2}{|c|}{25.5} & 31.6 & 34.6 & & 25.5 & 31.7 & 34.9 & & \\
\hline \multirow[t]{2}{*}{ L.S.D. 5\% } & A: & 2.7 & B: & 2.2 & $\mathrm{AB}: 4.4$ & A: 3.0 & B: & 2.4 & AB: & 4.9 \\
\hline & \multicolumn{10}{|c|}{ Fruit yield/plant (g) } \\
\hline $\mathbf{0}$ & \multicolumn{2}{|c|}{17.4} & 20.3 & 22.0 & 19.9 & 17.7 & 21.6 & 23.1 & & 20.8 \\
\hline 5 & \multicolumn{2}{|c|}{19.8} & 23.8 & 25.2 & 22.9 & 20.1 & 23.8 & 25.4 & & 23.1 \\
\hline 10 & \multicolumn{2}{|c|}{20.9} & 25.6 & 28.7 & 25.1 & 22.0 & 26.7 & 29.0 & & 25.9 \\
\hline 15 & \multicolumn{2}{|c|}{21.6} & 26.9 & 29.4 & 26.0 & 23.2 & 27.5 & 30.2 & & 27.0 \\
\hline Mean NPK & \multicolumn{2}{|c|}{19.7} & 24.2 & 26.3 & & 20.8 & 24.9 & 26.9 & & \\
\hline \multirow[t]{2}{*}{ L.S.D. 5\% } & A: & 2.3 & B: & 1.8 & AB: 3.6 & A: 1.8 & B: & 1.4 & AB: & 2.9 \\
\hline & \multicolumn{10}{|c|}{ Fruit yield/fed (kg) } \\
\hline $\mathbf{0}$ & \multicolumn{2}{|c|}{773} & 901 & 977 & 884 & 786 & 959 & 1026 & & 924 \\
\hline 5 & \multicolumn{2}{|c|}{879} & 1057 & 1119 & 1015 & 892 & 1057 & 1128 & & 1026 \\
\hline 10 & \multicolumn{2}{|c|}{928} & 1137 & 1274 & 1113 & 977 & 1185 & 1288 & & 1150 \\
\hline 15 & \multicolumn{2}{|c|}{959} & 1194 & 1305 & 1153 & 1030 & 1221 & 1341 & & 1197 \\
\hline Mean NPK & \multicolumn{2}{|c|}{885} & 1077 & 1169 & & 921 & 1106 & 1196 & & \\
\hline L.S.D. 5\% & A: & 74 & B: & 82 & AB: 164 & A: 81 & B: & 86 & AB: & 172 \\
\hline
\end{tabular}

NPK/plot) fertilization levels in comparison with those of control plants. In agreement with these results were those of Badran et al. (2001) and Tanious (2008) on fennel; Badran et al. (2003a), Badran et al. (2003b) and Hemdan (2008) on anise; Gahory (2012) on black cumin and Badran et al. (2013) on coriander.

The obtained results in Table (3) for the essential oil parameters indicated significant differences, in both seasons, due the interactions between organic and mineral fertilization. The best results were given when coriander plants received 15 ton compost/fed with $50 \mathrm{~g} \mathrm{NPK} /$ plot, as well as, either 10 or 15 ton compost/fed with $100 \mathrm{~g}$ NPK/plot with no significant differences between such three combined treatments. Therefore, the first one (15 ton compost/fed $\times 50 \mathrm{~g} \mathrm{NPK} /$ plot) would be the best choice from the economical and environmental point of view.

\section{Chemical composition:}

Each of herb nitrogen, phosphorus and potassium \% was significantly and gradually increased parallel to the gradual increase in compost level. The highest $\mathrm{N}, \mathrm{P}$ and $\mathrm{K} \%$ were given, in the two seasons, by the addition of the high compost level (15 ton/fed) as clearly shown in Table (4). Similar results were revealed by Fernandez et al. (2002) and Tanious (2008) on fennel; Younis et al. (2004) on Ammi visnaga; Abdalla (2009) on coriander and Gahory (2012) on black cumin.

The high NPK mineral fertilization treatment (100 g/plot) proved to be, significantly, more effective than both control and low NPK level (50 g/plot) as shown in Table (4). Similarly, the low NPK 


\section{F.S. Badran et al.}

Table 3. Effect of mineral and organic fertilization treatments on essential oil parameters of coriander plants during 2012/2013 and 2013/2014 seasons.

\begin{tabular}{|c|c|c|c|c|c|c|c|c|c|c|c|}
\hline \multirow{3}{*}{$\begin{array}{l}\text { Compost level } \\
\text { (ton/fed) (A) }\end{array}$} & \multicolumn{11}{|c|}{ NPK fertilization treatments $\left(\mathrm{g} / 10.8 \mathrm{~m}^{2}\right.$ plot) (B) } \\
\hline & $\mathbf{0}$ & 50 & 100 & & M. (A) & 0 & & 50 & 100 & & M. (A) \\
\hline & \multicolumn{7}{|c|}{ First season } & \multicolumn{4}{|c|}{ Second season } \\
\hline & \multicolumn{11}{|c|}{ Essential oil (\%) } \\
\hline $\mathbf{0}$ & 0.202 & 0.233 & \multicolumn{2}{|l|}{0.251} & 0.229 & 0.2 & & 0.247 & \multicolumn{2}{|l|}{0.256} & 0.238 \\
\hline 5 & 0.224 & 0.251 & 0.286 & & 0.254 & 0.2 & & 0.271 & \multicolumn{2}{|l|}{0.298} & 0.268 \\
\hline 10 & 0.255 & 0.286 & 0.319 & & 0.287 & 0.2 & & 0.292 & \multicolumn{2}{|l|}{0.316} & 0.291 \\
\hline 15 & 0.263 & 0.303 & 0.324 & & 0.297 & 0.2 & & 0.308 & \multicolumn{2}{|l|}{0.320} & 0.300 \\
\hline Mean NPK & 0.238 & 0.268 & 0.295 & & & 0.2 & & 0.280 & \multicolumn{2}{|l|}{0.298} & \\
\hline \multirow[t]{2}{*}{ L.S.D. 5\% } & A: $\quad 0.022$ & B: & 0.018 & AB: & 0.036 & A: & 0.016 & B: & 0.013 & AB: & 0.026 \\
\hline & \multicolumn{11}{|c|}{ Essential oil yield/plant (cm) } \\
\hline $\mathbf{0}$ & 0.035 & 0.047 & 0.055 & & 0.048 & 0.0 & & 0.053 & \multicolumn{2}{|l|}{0.059} & 0.05 \\
\hline 5 & 0.044 & 0.06 & 0.072 & & 0.059 & 0.0 & & 0.064 & \multicolumn{2}{|l|}{0.076} & 0.062 \\
\hline 10 & 0.053 & 0.073 & 0.092 & & 0.073 & 0.0 & & 0.078 & \multicolumn{2}{|l|}{0.092} & 0.076 \\
\hline 15 & 0.057 & 0.082 & 0.095 & & 0.078 & 0.0 & & 0.085 & \multicolumn{2}{|l|}{0.097} & 0.082 \\
\hline Mean NPK & 0.047 & 0.066 & 0.079 & & & 0.0 & & 0.07 & \multicolumn{2}{|l|}{0.081} & \\
\hline \multirow[t]{2}{*}{ L.S.D. 5\% } & A: $\quad 0.005$ & B: & 0.007 & AB: & $: 0.014$ & A: & 0.006 & B: & 0.008 & AB: & 0.017 \\
\hline & \multicolumn{11}{|c|}{ Essential oil yield/fed (liter) } \\
\hline $\mathbf{0}$ & 1.55 & 2.09 & 2.44 & & 2.03 & 1. & & 2.35 & 2.62 & & 2.22 \\
\hline 5 & 1.95 & 2.66 & 3.20 & & 2.60 & 2. & & 2.84 & 3.37 & & 2.77 \\
\hline 10 & 2.35 & 3.24 & 4.08 & & 3.22 & 2.5 & & 3.46 & 4.08 & & 3.37 \\
\hline 15 & 2.53 & 3.64 & 4.22 & & 3.46 & 2.8 & & 3.77 & 4.31 & & 3.63 \\
\hline Mean NPK & 2.10 & 2.91 & 3.49 & & & 2.2 & & 3.11 & 3.59 & & \\
\hline L.S.D. 5\% & A: $\quad 0.24$ & B: & 0.30 & AB: & $: 0.61$ & A: & 0.26 & B: & 0.29 & AB: & 0.58 \\
\hline
\end{tabular}

level gave significantly higher, $\mathrm{N}, \mathrm{P}$ and $\mathrm{K} \%$ than those of control plants. These results proved to be true in the two experimental seasons. In close agreement with these results were the findings of Badran et al. (2001) and Badran et al. (2007) on fennel; Badran et al. (2003a) on anise, Badran et al. (2009) and Badran et al. (2012) on black cumin and Badran et al. (2013) on coriander.

The interaction between organic and NPK mineral fertilization treatments was significant, in both seasons, for herb $\mathrm{N}, \mathrm{P}$ and $\mathrm{K} \%$ with the highest values being due to 15 ton compost/fed in combination with 100 g NPK/plot as illustrated in Table (4).

The beneficial role of organic fertilization in enhancing growth, fruit yield, essential oil and $\mathrm{N}, \mathrm{P}$ and $\mathrm{K} \%$ in coriander plants may be attributed to the fact that organic manure minimizes the loss of nutrients by leaching and forms considerable amounts of humus during the decomposition of organic manure, whether in composts or soils, leads to significant increase in microbial activities in the root zones, improves soil permeability and releases carbon dioxide and certain organic acids during decomposition, (Saber, 1997 and Mashali, 1997).

The superiority of mineral NPK fertilization could be interpreted in the light of the unique biological and physiological roles of each one of such essential nutrients in plant growth and development. Nitrogen is a constituent of the protoplasm and most organic compounds, i.e. amino acids, nucleic acids RNA and DNA, enzymes, alkaloids, vitamins, phosphatides, purine and many energy transfer materials such as chlorophylls, ADP and ATP. Phosphorus is essential for cell division and meristem tissue development. It is involved in the 
Table 4. Effect of mineral and organic fertilization treatments on $\mathrm{N}, \mathrm{P}$ and $\mathrm{K} \%$ in the herb of coriander plants during 2012/2013 and 2013/2014 seasons.

\begin{tabular}{|c|c|c|c|c|c|c|c|c|c|}
\hline \multirow{3}{*}{$\begin{array}{l}\text { Compost level } \\
\text { (ton/fed) (A) }\end{array}$} & \multicolumn{9}{|c|}{ NPK fertilization treatments $\left(\mathrm{g} / \mathbf{1 0 . 8} \mathrm{m}^{2}\right.$ plot) (B) } \\
\hline & $\mathbf{0}$ & 50 & 100 & M. (A) & $\mathbf{0}$ & 50 & 100 & & M. (A) \\
\hline & \multicolumn{4}{|c|}{ First season } & \multicolumn{5}{|c|}{ Second season } \\
\hline & \multicolumn{9}{|c|}{ Herb nitrogen (\%) } \\
\hline $\mathbf{0}$ & 1.54 & 1.77 & 1.94 & 1.75 & 1.42 & 1.68 & 1.80 & & 1.63 \\
\hline 5 & 1.68 & 1.91 & 2.29 & 1.96 & 1.59 & 1.81 & 2.18 & & 1.86 \\
\hline 10 & 1.82 & 2.18 & 2.54 & 2.18 & 1.78 & 2.15 & 2.36 & & 2.10 \\
\hline 15 & 2.06 & 2.37 & 2.67 & 2.37 & 1.98 & 2.31 & 2.58 & & 2.29 \\
\hline Mean NPK & 1.78 & 2.06 & 2.36 & & 1.69 & 1.99 & 2.23 & & \\
\hline \multirow[t]{2}{*}{ L.S.D. 5\% } & A: $\quad 0.10$ & B: & 0.12 & AB: 0.24 & A: $\quad 0.08$ & B: & 0.09 & AB: & 0.18 \\
\hline & \multicolumn{9}{|c|}{ Herb phosphorus (\%) } \\
\hline $\mathbf{0}$ & 0.214 & 0.246 & 0.273 & 0.277 & 0.208 & 0.24 & 0.262 & & 0.237 \\
\hline 5 & 0.231 & 0.284 & 0.321 & 0.279 & 0.225 & 0.271 & 0.309 & & 0.268 \\
\hline 10 & 0.264 & 0.312 & 0.353 & 0.31 & 0.254 & 0.306 & 0.332 & & 0.297 \\
\hline 15 & 0.286 & 0.336 & 0.382 & 0.335 & 0.27 & 0.324 & 0.355 & & 0.316 \\
\hline Mean NPK & 0.249 & 0.295 & 0.332 & & 0.239 & 0.285 & 0.315 & & \\
\hline \multirow[t]{2}{*}{ L.S.D. 5\% } & 0.013 & B: & 0.011 & 0.022 & 0.015 & B: & 0.016 & AB: & 0.032 \\
\hline & \multicolumn{9}{|c|}{ Herb potassium (\%) } \\
\hline $\mathbf{0}$ & 0.725 & 0.802 & 1.014 & 0.847 & 0.666 & 0.81 & 0.906 & & 0.794 \\
\hline 5 & 0.792 & 0.857 & 1.078 & 0.909 & 0.717 & 0.844 & 0.983 & & 0.848 \\
\hline 10 & 0.891 & 0.982 & 1.138 & 1.004 & 0.788 & 0.921 & 1.071 & & 0.927 \\
\hline 15 & 0.934 & 1.092 & 1.283 & 1.103 & 0.846 & 0.957 & 1.156 & & 0.986 \\
\hline Mean NPK & 0.836 & 0.933 & 1.128 & & 0.754 & 0.883 & 1.029 & & \\
\hline L.S.D. 5\% & A: $\quad 0.042$ & B: & 0.032 & AB: 0.064 & A: 0.038 & $\mathrm{~B}:$ & 0.040 & AB: & 0.080 \\
\hline
\end{tabular}

phosphorylation processes which cause production of higher energy compounds (ADP and ATP). It has fundamental roles in different enzymatic reactions and important in photosynthesis, interconversion of carbohydrates, amino acid metabolysis, fat metabolism and biological oxidation. Potassium serves as a metabolic regulator or catalyst. It is essential for nitrogen metabolism, various enzyme activation and promotion of the meristematic tissue growth. It aids in the uptake of other nutrients and in their movement in the plant. Moreover, the presence of potassium ion in the solution helps in maintaining the osmotic concentration necessary for cell turgidity which is essential for the adjustment of stomatal movement and water relations. It is also necessary for the metabolism of carbohydrates and their translocation from the plant leaves to the roots.
The results obtained in the present experiment revealed that reducing the rate of NPK fertilization from 100 to 50 g/plot in combination which 10 or 15 ton compost/fed gave reasonable fruit yield and essential oil production of coriander plants which is economically and environmentally acceptable.

\section{REFERENCES}

Abdalla, M.Y. (2009). Effect of organic, bio and mineral fertilization on growth, yield, oil productivity and chemical constituents of coriander plant. J. Agric. Sci., Mansoura Univ., 34(5):5195-5208.

Badran, F.S.; Abdalla, N.M.; Aly, M.K. and Ibrahim, S.M. (2007). Response of fennel plants to seeding rate and partial replacement of mineral NPK by biofertilization treatments. Proc. $8^{\text {th }}$ 


\section{F.S. Badran et al.}

African crop. Sci. Conf. Minia, Egypt, Vol. 8, Part I:417-422.

Badran, F.S.; Aly, M.K. and Abd-Ellatif, M.Z. (2009). Response of Nigella sativa, L. plants to plant density and mineral/biofertilization treatments. Proc. $7^{\text {th }}$ Inter'n Conf. of Organic Agric., Cairo, Egypt. J. Agric. Res., 87(1):185-195.

Badran, F.S.; Aly, M.K. and Abd-Ellatif, M.Z. (2012). Influence of NPK, biofertilizers and micronutrients on Nigella sativa, L. plants. Proc. Minia Inter'n Conf. for Agric. \& Irrig. In the Nile Basin Countries. March 2012, Minia, Egypt.

Badran, F.S.; Aly, M.K.; Hassan, E.A. and Shalatet, Sh.G. (2007). Effect of organic and biofertilization treatments on cumin plants. Proc. $3^{\text {rd }}$ Conf. of Sustainable Agric. \& Dev., Fayoum, Egypt, Nov. 2007:371-380.

Badran, F.A.; Attia, F.A.; Ahmed, E.T. and Soliman, H.S. (2003a). Effect of chemical- and bio- fertilization on growth, yield and oil production of anise (Pimpinella anisum, L.) plants. I- Effect of different potassium and phosphorus rates. Proc. $1^{\text {st }}$ Egypt- Syrian Conf. for Agric. \& Food, Minia Egypt, 1(1):103112.

Badran, F.S.; Attia, F.A.; Ahmed, E.T. and Soliman, H.S. (2003b). Effect of chemical - and bio- fertilization on growth, yield and oil production of anise (Pimpinella anisum, L.) plants. II. Effect of NP mineral/biofertilizers and micronutrient treatments. Proc. $1^{\text {st }}$ EgyptSyrian Conf. for Agric. \& Food, Minia, Egypt, 1(1):113-124.

Badran, F.S.; Attia, F.A. and Ayat, A.M. (2011). Response of coriander (Coriandrum sativum, L.) plants, grown in new reclaimed land, to NPK fertilization and antioxidant treatments . Inter'n Conf. on Total Quality Management of Herb \& Medic. Plants and their Products, Egypt, Dec. 6-8, 2011.
Badran, F.S.; Attia, F.A. and Ayat, A.M. (2013). Effect of macro/micro fertilization treatments, as well as, salicylic and ascorbic acids on growth, fruit yield and essential oil of coriander plants grown in sandy soil. $1^{\text {st }}$ Assiut Inter'n Conf. of Hort. Feb. 24- 27.

Badran, F.S. and Safwat, M.S. (2004). Response of fennel plants to organic manure and bio- fertilizers in replacement of chemical fertilization. Egyptian J. Agric. Res., 82(2).

Badran, F.S.; Safwat, M.S. and Zayed, G.A. (2001). Is it possible to supply fennel plants with organic- and bio- fertilizers in replacement of mineral fertilizers. ElSalam Canal Symposium, North Sinai, Egypt, May 7-10, 2001.

Bedoukian, PO.Z. (1967). Perfumery and flavoring synthesis. 223. El-Sevier publishing Co.

Bhuvaneshwari, F.; Sreeramu, B.S. and Srinivasa, K.N. (2003). Influence of nitrogen, phosphprus and potassium levels on growth, seed yield and essential oil content in anise. J. of Spices and Aromatic Crops, 11(2):112-117 (C.F. Hort. Abst., 73 (12): 11071).

Fernandez, D.M.; Doi, N.T.; Villas, R.L.; Bull, L.T. and Miazaki, S.S. (2002). Macronutrients and micronutrients removed by aerial part of sweet fennel due to liming and chicken manure fertilization. Acta Hort., 569: 185-190.

Gad, A.M.; El-Dakhakhny, M. and Hassan, M.M. (1963). Studies on the chemical constituation of Egyptian Nigella sativa, L. oil. Planta Medica, 11:134-138.

Gahory, A.M. (2012). Physiological Studies on Black Cumin Plant. Ph.D. Thesis, Fac. Agric., Minia Univ.

Hemdan, Sh. H. (2008). Effect of Some Organic and Biofertilization Treatments on Anise Plants. M.Sc. Thesis, Fac. Agric. Minai Univ. 
Joshi, D.N.; Bhojvaid, P.P. and Dobriyal, M.J. (2003). Effect of chemical fertilizers (NPK) on seed production of Ammi majus, Linn. and analysis of cultivation cost. International J. of Forest Usufructs Management, 4(1):59-63.

Kenawy, A.G. (2010). Response of Ammi visnaga, L. Plants to Some Organic and Biofertilization Treatments, Ph.D. Thesis, Fac. of Agric., Minia Univ.

Little, I.M. and Hills, F.J. (1978). Agricultural Experimentation Design \& Analysis. John Wiley and Sons Inc., New York, USA.

Mashali, A.M. (1997). FAO global network on integrated soil management for sustainable use of salt affected soils in the arid ecosystm. Proc. Inter'n Symposium, Sept. 1997, cairo, Egypt, 31- 51.

Moradi, R.; Moghaddam, P.R.; Mahallati, N.M. and Nezhadali, A. (2011). Effects of organic and biological fertilizers on fruit yield and essential oil of sweet fennel (Foeniculum vulgare var. dulce) Spain J. of Agric. Res., 9(2):546-553

Page, A.L.; Miller, R.H. and Kenney, D.R. (1982). Methods of Soil Analysis, Part II. Amer. Soc. Agronomy Inc., Madison, Wisconsin, U.S.A.
Saber, M.S. (1997). Biofertilized Farming System. Proc. of the Training Course on Bio Organic Farming Systems for Sustainable Agric, 16-72.

Safwat, M.S. and Badran, F.S. (2002). Efficiency of organic and biofertilizers in comparison with chemical fertilization, on growth, yield and essential soil of cumin plants. Proc. $9^{\text {th }}$ Conf. of Medicinal and Aromatic Plants, Cairo, Egypt.

Shoor, M.; Khalesi, N.; Kazemi, M.S. and Yazdi, K. (2010). Effect of organic manure and nitrogen fertilizer on yield, essence and extract of black cumin (Nigella sativa, L.). Proc. Inter'n Medicinal and Aromatic Plants Symposium, June 21- 23, Shiraz, Iran.

Stary, F. and Jirasck, V. (1975). A concise Guide in Color Herbs. Hamlin, London, New York, Sydney, Toronto.

Tanious, C.T. (2008). Effects of Some Organic and Biofertilization Treatments on Fennel Plants. M.Sc. Thesis, Fac. of Agric., Minia Univ.

Younis, S.I.; Ghaly, N.A. and Ahmed, Sh. K. (2004). Effect of FYM and planting space on vegetative growth, active ingredients and chemical composition of Ammi visnaga, L. J. Agric. Sci., Mansoura Univ., 29(4):1985-1993. 


\section{F.S. Badran et al.}

وللفدان) والنسبة المئوية للنتروجين و الفوسفور والبوتاسيوم فى العشب قد زادت زيادة تدريجية بالتلازم مع الزيادة

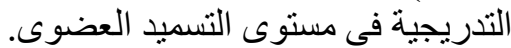

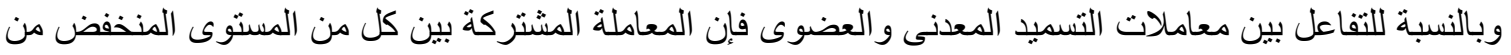

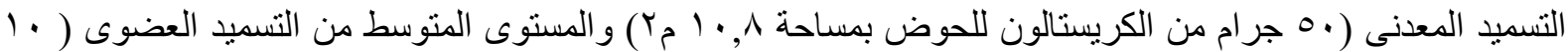

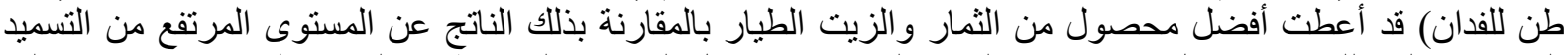

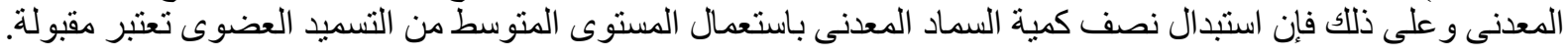

